\title{
KETAHANAN PANGAN RUMAH TANGGA DI KABUPATEN CIAMIS
}

\author{
Asep Herdiana $^{1)}$, Dwidjono Hadi Darwanto ${ }^{2)}$, Jangkung Handoyo Mulyo ${ }^{23)}$ \\ ${ }^{1}$ Badan Ketahanan Pangan, Kementerian Pertanian \\ ${ }^{2}$ Fakultas Pertanian, Universitas Gadjah Mada \\ ${ }^{3}$ Peneliti pada Pusat Kependudukan dan Kebijakan (PSKK), Universitas Gadjah Mada \\ E-mail: herdiana_asep@yahoo.com
}

\begin{abstract}
Food security at the national or regional level does not ensure food security at the household and individual level. Benchmark attainment of food security at the household level is ensuring the physical and economic accessibility to food. This research aims to determine the household food security level in the district of Ciamis and the factors that influence it by using table analysis and ordinal probit regression models. Data used in this study is National Social Economic Survey (SUSENAS) 2012 from Central Beaureu of Statistic (BPS). In 2012, there are still households who can not stand the food, this is indicated by the distribution of households by level of household food security, it can be seen from the distribution of households by level of food security based on Jonsson and Toole method are: vulnerable households 530 (54.08\%), household food security 264 (26.94\%), insecure households 124 (12.65\%) and households less food $62(6.33 \%)$, while according to the modified method are: vulnerable households $592(60,41 \%)$, household food security 264 (26.94 \%) and insecure households 124 (12.65\%). Householdincome,household head education, household size, ownership of rice, food base animal price and cooking oils price were found to be significant determinants of household food security level in the study area.
\end{abstract}

Keywords: Household Food Security, Ordinal Probit.

\begin{abstract}
Abstrak: Ketahanan pangan di tingkat nasional atau regional belum tentu menjamin ketahanan pangan di tingkat rumah tangga atau individu. Tolok ukur pencapaian ketahanan pangan rumah tangga adalah terjaminnya akses fisik dan ekonomi terhadap pangan.Penelitian ini bertujuan untuk mengetahui ketahanan pangan rumah tangga di Kabupaten Ciamis dan faktor yang mempengaruhinya, menggunakan analisis regresi model ordinal probit.Data yang digunakan bersumber dari data SUSENAS 2012 dari BPS.Pada tahun 2012, di Kabupaten Ciamis masih terdapat rumah tangga yang tidak tahan pangan.Hal tersebut terlihat dari distribusi rumah tangga menurut tingkat ketahanan pangan. Berdasarkan metode Jonsson dan Toole terdapat rumah tangga rentan pangan $530(54.08 \%)$, rumah tangga tahan pangan 264 (26.94\%), rumah tangga rawan pangan $124(12.65 \%)$ dan rumah tangga kurang pangan $62(6.33 \%)$, sedangkan menurut modifikasi metode Jonsson dan Toole terdapat rumahtangga rentan pangan $592(60,41 \%)$, rumah tangga tahan pangan 264(26.94\%) dan rumah tangga rawan pangan 124 (12.65\%).Pendapatan rumah tangga, lama pendidikan kepala rumah tangga, jumlah anggota rumah tangga, jumlah beras yang tersedia untuk dikonsumsi, harga kelompok bahan pangan hewani dan kelompok pangan minyak dan lemak berpengaruh terhadap tingkat ketahanan pangan rumah tangga.
\end{abstract}

Kata kunci: Household Food Security, Ordinal Probit.

PENDAHULUAN

Pangan adalah salah satu kebutuhan dasar manusia yang pemenuhannya merupakan bagian dari hak asasi manusia dan sebagai komponen dasar untuk mewujudkan sumber 
daya manusia yang berkualitas.Oleh karena itu pangan harus tersedia secara cukup, aman, bermutu, bergizi dan beragam dengan harga yang terjangkau oleh daya beli serta tidak bertentangan dengan keyakinan dan budaya masyarakat (DKP, 2012).

Lebih lanjut UU No. 18/2012 tentang Pangan mengatakan bahwa setiap negara akan berusaha untuk dapat mewujudkan ketahanan pangan yang tercermin dari ketersediaan, keterjangkauan, dan pemenuhan konsumsi pangan baik pada tingkat nasional, daerah sampai dengan individu secara merata sepanjang waktu dengan memanfaatkan sumber daya, kelembagaan dan budaya lokal.

\begin{tabular}{llrr}
\multicolumn{2}{c}{ Pemantapan } & ketahanan & pangan \\
mempunyai peran & strategis & dalam \\
pembangunan & nasional, karena: (1) akses
\end{tabular}
terhadap pangan dengan gizi yang cukup merupakan hak yang paling asasi bagi manusia; (2) kualitas pangan dan gizi yang dikonsumsi merupakan unsur penentu bagi pembentukan sumber daya manusia yang berkualitas: dan (3) ketahanan pangan merupakan salah satu pilar utama yang menopang ketahanan ekonomi dan ketahanan nasional. Kekurangan pangan tidak hanya akan berdampak kondisi sosial ekonomi tetapi juga dapat menyebabkan terjadinya gejolak stabilitas politik nasional (BKP, 2009).

Ketahanan pangan mensyaratkan ketersediaan pangan yang cukup bagi setiap individu agar mampu mengkonsumsi pangan dalam jumlah dan kualitas gizi yang cukup.Namun, produksi dan ketersediaan pangan yang cukup di tingkat wilayah tidak secara otomatis menjamin ketahanan pangan rumah tangga.Ketahanan pangan rumah tangga dapat dicapai apabila rumah tangga memiliki kemampuan untuk memperoleh pangan yang cukup, bergizi, aman, yang dapat mendukung hidup sehat dan produktif.

Hasil analisis tingkat kerentanan terhadap kerawanan pangan wilayah pada Peta Ketahanan dan Kerentanan Pangan/Food Security and Vulnerability Atlas-FSVA tahun 2005 dan 2009 menunjukkan bahwa Kabupaten Ciamis pada tahun2005 menempati peringkat ke 189 dari 265 kabupaten di Indonesia (DKP, 2005).Sedangkan pada tahun 2009 Kabupaten Ciamis menempati peringkat ke 298 dari 346 kabupaten di Indonesia (DKP, 2009).Hal tersebut menggambarkan bahwa Kabupaten Ciamis secara kewilayahan memiliki tingkat kerentanan terhadap kerawanan pangan lebih kecil dibandingkan dengan wilayah lainnya, atau dengan kata lain tingkat ketahanan wilayah Kabupaten Ciamis lebih baik dibandingkan kabupaten lainnya di Indonesia.

Namun demikian, ketahanan pangan di tingkat nasional atau regional tidak menjamin ketahanan pangan di tingkat rumah tangga dan individu.

Berdasarkan hal tersebut diatas, penelitian ini bertujuan untuk mengetahui tingkat ketahanan pangan rumah tangga di Kabupaten Ciamis dan faktor-faktor yang mempengaruhinya.

\section{KAJIAN LITERATUR}

Ketahanan pangan merupakan salah satu variabel strategis dalam pembangunan nasional. Pembangunan ketahanan pangan nasional diarahkan untuk meningkatkan ketersediaan pangan, penanganan kerawanan pangan dan akses pangan; meningkatkan sistem distribusi dan stabilisasi harga pangan; dan cadangan pangan; serta meningkatkan pemenuhan kebutuhan konsumsi dan keamanan pangan (DKP, 2010).

Pemahaman mengenai ketahanan pangan dimulai pada kurun waktu tahun 1950-1960 dan tahun 1970-an. Pada jangka waktu tersebut, pemahaman ketahanan pangan lebih menekankan perhatiannya pada ketersediaan pangan, baik pada tingkat global maupun tingkat nasional daripada tingkat rumah tangga, sehingga sasaran pembangunan ketahanan pangan pada periode tersebut adalah menyediakan pangan yang cukup untuk seluruh penduduk. Pendekatan ini belum memasukkan unsur distribusi dan aspek akses pangan. Asumsi yang mendasari pendekatan ini adalah bahwa jika persediaan pangan terpenuhi maka para pedagang dapat menyalurkan pangan secara merata dan efisien sehingga harga pangan akan stabil dan dapat terjangkau oleh masyarakat (Suryana, 2007).

Namun, meski persediaan pangan cukup, masih dijumpai sebagian masyarakat menderita kelaparan karena tidak memiliki akses terhadap pangan.Hal ini menunjukkan bahwa kondisi ketersediaan pangan yang cukup pada tingkat wilayah tidak secara otomatis menunjukkan kondisi ketahanan pangan pada tingkat individu maupun rumah tangga. 
Pendekatan ketahanan pangan rumah tangga mulai berkembang pada tahun 1980-an, menekankan baik pada aspek ketersediaan maupun aspek akses yang stabil terhadap pangan. Dengan demikian, pemahaman ketahanan pangan pada periode ini menekankan dua aspek penting dalam ketahanan pangan, yaitu ketahanan pangan dalam arti ketersediaan pangan maupun akses yang stabil.

Evolusi pemikiran ketahanan pangan diabstraksikan oleh Simatupang dalam Suryana (2007) dengan klasifikasi sebagai berikut:

a. Pendekatan ketersediaan pangan (Food Availability Approach) diadopsi luas hingga tahun 1980-an. Swasembada pangan (Food Selfsufficiency) khususnya swasembada beras termasuk dalam paradigma ini.

b. Pendekatan perolehan pangan (Food Entitlement Approach) dipelopori oleh peraih Nobel Armantya Sen pada awal tahun 1980-an. Selain ketersediaan pangan, akses terhadap pangan juga menjadi salah satu dimensi pokok ketahanan pangan.

c. Pendekatan ketahanan pangan berkelanjutan (Sustainable Food Security) berkembang pada tahun 1990-an, menekankan kaitan ketahanan pangan, kemiskinan dan kelestarian lingkungan.

d. Pendekatan Nutritional Food Security yang menekankan pentingnya aspek zat nutrisi pangan di tingkat individu. Konsep ini mengingatkan bahwa ketahanan pangan tidak selalu dapat menjamin ketahanan nutrisi.

e. Pendekatan kedaulatan pangan (Food Sovereignity) yang berkembang pada tahun 2000-an, menekankan perlunya kemandirian pangan setiap negara, terutama negara-negara berkembang.

Penyelenggaraan pangan dilakukan untuk memenuhi kebutuhan dasar manusia yang memberikan manfaat secara adil, merata, dan berkelanjutan berdasarkan Kedaulatan Pangan, Kemandirian Pangan, dan Ketahanan Pangan.Program ketahanan pangan tersebut diarahkan pada kemandirian masyarakat yang berbasis sumberdaya lokal yang secara operasional dilakukan melalui program peningkatan produksi pangan; menjaga ketersediaan pangan yang cukup, aman dan halal di setiap daerah setiap saat; dan antisipasi agar tidak terjadi kerawanan pangan (Darwanto, 2005).

Sebagai sebuah sistem, ketahanan pangan terdiri atas beberapa sub sistem yang memiliki fungsi masing-masing, saling berinterkasi dan ketergantungan, yaitu: penyediaan, penyaluran, dan pemanfaatan. Ketiga subsistem tersebut merupakan suatu rangkaian yang berurutan dan utuh, apabila salah satu sub sistem tersebut tidak dipenuhi, maka ketahanan pangan belum tentu tercapai.

Di dalam sistem ketahanan pangan nasional, pencapaian ketahanan pangan dimulai pada tingkat rumah tangga. Tolok ukur pencapaian ketahanan pangan pada tingkat rumah tangga adalah terjaminnya aksesibilitas fisik dan ekonomi atas pangan, bukan hanya pada kemampuan rumah tangga untuk memproduksi sendiri (Suryana, 2007). Walaupun pangan tersedia di tingkat nasional dan regional, tetapi jika akses individu untuk memenuhi kebutuhannya tidak merata, maka ketahanan pangan masih dikatakan rapuh (Hanani, 2012).

Output dari pemenuhan ketahanan pangan adalah pemenuhan HAM atas pangan, peningkatan kualitas SDM, ketahanan nasional, sedangkan status gizi merupakan outcome dari ketahanan pangan.

Sejalan dengan evolusi pemikiran tentang ketahanan pangan, definisi ketahanan pangan dirumuskan secara beragam dan berkembang sesuai dengan sudut pandang dan kepentingan masing-masing, baik pada tataran global maupun nasional. Ketahanan pangan merupakan terjemahan dari food security mencakup banyak aspek, mulai dari ketersediaan, distribusi dan konsumsi pangan sehingga dapat diinterpretasikan dengan banyak cara. Definisi ketahanan pangan berubah dari satu periode waktu ke periode waktu lainnya (Wiganda dalam Suryana 2003).

Pengertian ketahanan pangan menurut Undang-Undang Nomor 18 Tahun 2012 tentang Pangan, dijelaskan sebagai Kondisi terpenuhinya pangan bagi negara sampai dengan perseorangan, yang tercermin dari tersedianya pangan yang cukup, baik jumlah maupun mutunya, aman beragam, bergizi, merata, dan terjangkau serta tidak bertentangan dengan agama, keyakinan dan budaya masyarakat, untuk dapat hidup sehat, aktif, dan produktif secara berkelanjutan. 
Ketahanan pangan memiliki kaitan dengan kerawanan pangan, yang diartikan sebagai kondisi ketidakmampuan untuk memenuhi kebutuhan pangan minimum. Kerawanan pangan merupakan suatu kondisi ketidakcukupan pangan yang dialami oleh suatu daerah, masyarakat atau rumah tangga pada waktu tertentu untuk memenuhi standar kebutuhan fisiologis bagi pertumbuhan dan kesehatan masyarakat (Ariningsih dan Rachman, 2008).

Tolok ukur pencapaian tujuan pembangunan ketahanan pangan dijabarkan secara kuantitatif pada keragaan di tingkat individu, yaitu: (1) mempertahankan ketersediaan energi dan protein per kapita minimal masing-masing $2.200 \mathrm{kkal} / \mathrm{hari}$ dan 57 gr/hari; (2) meningkatkan konsumsi pangan untuk memenuhi kecukupan energi dan protein per kapita minimal $2.000 \mathrm{kkal} / \mathrm{hari}$ dan 52 gr/hari; (3) meningkatkan kualitas konsumsi pangan yang diukur oleh skor $\mathrm{PPH}$ (Pola Pangan Harapan) sebesar minimal 80; (4) meningkatkan keamanan, mutu dan kesehatan pangan yang dikonsumsi; (5) mengurangi penduduk rawan pangan kronis $(<80 \%$ Angka Kecukupan Gizi) dengan laju sebesar 1\%/tahun(DKP, 2006).

Terdapat tiga komponen utama pembentukan ketahanan pangan rumah tangga, yaitu produksi sendiri, cadangan pangan, dan pendapatan(Suryana, 2007).Bagi rumah tangga pertanian, komponen produksi pangan menjadi unsur utama, tetapi bagi rumah tangga nonpertanian komponen pendapatan menjadi komponen utama untuk memperoleh pangan.

Jonsson dan Toole (1991) dalam Maxwell et. all (2000), menjelaskan indikator ketahanan pangan rumah tangga, dengan metode klasifikasi silang antara pangsa pengeluaran pangan dan kecukupan energi, seperti pada Tabel 1.
Klasifikasi silang tersebut menghasilkan empat tingkat ketahanan pangan rumah tangga, yaitu:

a. rumah tangga tahan pangan, yaitu bila cukup mengkonsumsi energi $(>80 \%$ dari syarat kecukupan energi) dan proporsi pengeluaran pangan rendah $(<60 \%$ dari pengeluaran rumah tangga).

b. rumah tangga rentan pangan, yaitu bila cukup mengkonsumsi energi $(>80 \%$ dari syarat kecukupan energi) dan proporsi pengeluaran pangan tinggi $(\geq 60 \%$ dari pengeluaran rumah tangga).

c. rumah tangga kurang pangan, yaitu bila kurang mengkonsumsi energi $(\leq 80 \%$ dari syarat kecukupan energi) dan proporsi pengeluaran pangan rendah $(<60 \%$ dari pengeluaran rumah tangga).

d. rumah tangga rawan pangan, yaitu bila kurang mengkonsumsi energi $(\leq 80 \%$ dari syarat kecukupan energi) dan proporsi pengeluaran pangan tinggi $(\geq 60 \%$ dari pengeluaran rumah tangga).

Rumah tangga kurang pangan yang memiliki konsumsi energi rendah dan pangsa pengeluaran pangan rendahmenyebabkan kelompok rumah tangga ini sulit untuk dijelaskan. Hal ini mungkin disebabkan oleh adanya kesalahandalam pengukuran, seperti terlalu kecilnya konsumsi pangan dilaporkan atau terlalu besarnya pengeluaran pangan yang dilaporkan (Maxwell dkk., 2000).Oleh karena itu, dalam penelitian ini tingkat ketahanan pangan rumah tangga juga diukur dengan modifikasi metode Jonsson dan Toole, dengan menggabungkan rumah tangga kurang pangan dan rentan pangan, menjadi:

a. rumah tangga tahan pangan, yaitu bila cukup mengkonsumsi energi $(>80 \%$ dari syarat kecukupan energi) dan proporsi pengeluaran pangan rendah $(<60 \%$ dari pengeluaran rumah tangga).

Tabel 1.Klasifikasi Silang antara Pangsa Pengeluaran dan Kecukupan Energi

\begin{tabular}{lcc}
\hline \multicolumn{1}{c}{$\begin{array}{c}\text { Konsumsi energi per unit } \\
\text { ekuivalen dewasa }\end{array}$} & $\begin{array}{c}\text { Rendah } \\
\quad(<60 \% \text { pengeluaran total })\end{array}$ & $\begin{array}{c}\text { Tinggi } \\
(\geq 60 \% \text { pengeluaran total })\end{array}$ \\
$\begin{array}{l}\text { Cukup } \\
(>80 \% \text { kecukupan energi })\end{array}$ & Tahan Pangan & Rentan Pangan \\
$\begin{array}{l}\text { Kurang } \\
(\leq 80 \% \text { kecukupan energi) }\end{array}$ & Kurang Pangan & Rawan Pangan
\end{tabular}

Sumber: Jonsson dan Toole (1991) dalam Maxwell dkk., (2000). 
b. rumah tangga rentan pangan, yaitu bila cukup mengkonsumsi energi $(>80 \%$ dari syarat kecukupan energi) dan proporsi pengeluaran pangan tinggi $(\geq 60 \%$ dari pengeluaran rumah tangga) serta kurang mengkonsumsi energi $(\leq 80 \%$ dari syarat kecukupan energi) dan proporsi pengeluaran pangan rendah $(<60 \%$ dari pengeluaran rumah tangga).

c. rumah tangga rawan pangan, yaitu bila kurang mengkonsumsi energi $(\leq 80 \%$ dari syarat kecukupan energi) dan proporsi pengeluaran pangan tinggi $(\geq 60 \%$ dari pengeluaran rumah tangga).

Penelitian yang dilakukan oleh Rachman (2005) dan Purwantini (2007) mengukur ketahanan pangan rumah tangga dengan menggunkan tingkat ketahanan pangan rumah tangga dengan urutan: tahan pangan, rentan pangan, kurang pangan dan rawan pangan.Sedangkan Suharyanto (2014) menggunakan tingkat ketahanan pangan rumah tangga hasil modifikasi klasifikasi silang menggabungkan rumah tangga rentan pangan dan kurang pangan menjadi rumah tangga rentan pangan, dengan urutan tingkatan: tahan pangan, rentan pangan dan rawan pangan.

\section{METODE PENELITIAN}

Penelitian ini berdasarkan data Survey Sosial Ekonomi Nasional (SUSENAS) tahun 2012 dari Badan Pusat Statistik (BPS) dengan cakupan wilayah Kabupaten Ciamis.

Tingkat ketahanan pangan rumah tangga diukur dengan metode klasifikasi silang antara pangsa pengeluaran pangan dan kecukupan energi dari Jonsson dan Toole (1991) dalam Maxwell et. all (2000) dan modifikasi metode Jonsson dan Toole.

Analisis dengan menggunakan metode Jonsson dan Toole menghasilkan tingkatan ketahanan pangan rumah tangga, yaitu:

1 untuk rumah tangga tahan pangan;

2 untuk rumah tangga rentan pangan;

3 untuk rumah tangga kurang pangan, dan

4 rumah tangga tahan pangan.

Sedangkan dengan menggunakan modifikasi metode Jonsson dan Toole dengan menggabungkan rumah tangga rentan pangan dan kurang pangan menjadi rumah tangga rentan pangan, menghasilkan tingkatan ketahanan pangan rumah tangga, yaitu: 1)untuk rumah tangga tahan pangan;2) untuk rumah tangga rentan pangan; dan3) rumah tangga tahan pangan.

Untuk mengetahui faktor-faktor yang berpengaruh terhadap ketahanan pangan rumahtangga dilakukan analisis regresi model ordinal probit.Penggunaan model regresi ordinal probit dengan pertimbangan bahwa tingkat ketahanan panan rumah tangga sebagai variabel dependen bersifat ordinal/tingkatan.

Adapun persamaannya regresinya adalah sebagai berikut:

$$
\begin{aligned}
\frac{P_{k}}{1-P_{k}}=T K P & \\
& =\beta_{0}+\beta_{1} \ln X_{1} \\
& +\beta_{2} \ln X_{2}+\beta_{3} \ln X_{3} \\
& +\beta_{4} \ln X_{4}+\beta_{5} \ln X_{5} \\
& +\beta_{6} \ln X_{6}+\beta_{7} \ln X_{7} \\
& +\beta_{8} \ln X_{8}+\beta_{9} \ln X_{9} \\
& +\beta_{10} \ln X_{10} \\
& +\beta_{11} \ln X_{11} \\
& +\beta_{12} \ln X_{12} \\
& +\beta_{13} \ln X_{13} \\
& +\beta_{14} \ln X_{14} \\
& ++\beta_{15} \ln X_{15} \\
& +\beta_{16} D_{-} \text {wil } \\
& +\beta_{17} D_{-} \text {ras }+u
\end{aligned}
$$

Keterangan:

TKPk $=$ Tingkat ketahanan pangan rumah tangga.

Pada metode Jonsson dan Toole, $\mathrm{k}=$ $1,2,3$ dan 4

Probabilitas $\mathrm{P} 1=\mathrm{P}(\mathrm{Y}=1)$ bila rumah tangga rawan pangan

Probabilitas $\mathrm{P} 2=\mathrm{P}(\mathrm{Y}=2)$ bila rumah tangga kurang pangan

Probabilitas $\mathrm{P} 3=\mathrm{P}(\mathrm{Y}=3)$ bila rumah tangga rentan pangan

Probabilitas $\mathrm{P} 4=\mathrm{P}(\mathrm{Y}=4)$ bila rumah tangga tahan pangan

Sedangkan pada modifikasi metode Jonsson dan Toole, $\mathrm{k}=1$,2, dan 3.

Probabilitas $\mathrm{P} 1=\mathrm{P}(\mathrm{Y}=1)$ bila rumah tangga rawan pangan

Probabilitas $\mathrm{P} 2=\mathrm{P}(\mathrm{Y}=2)$ bila rumah tangga rentan pangan

Probabilitas $\mathrm{P} 3=\mathrm{P}(\mathrm{Y}=3)$ bila rumah tangga tahan pangan

$\mathrm{X} 1=$ pendapatan $(\mathrm{Rp})$

$\mathrm{X} 2=$ umur kepala rumah tangga (tahun) 


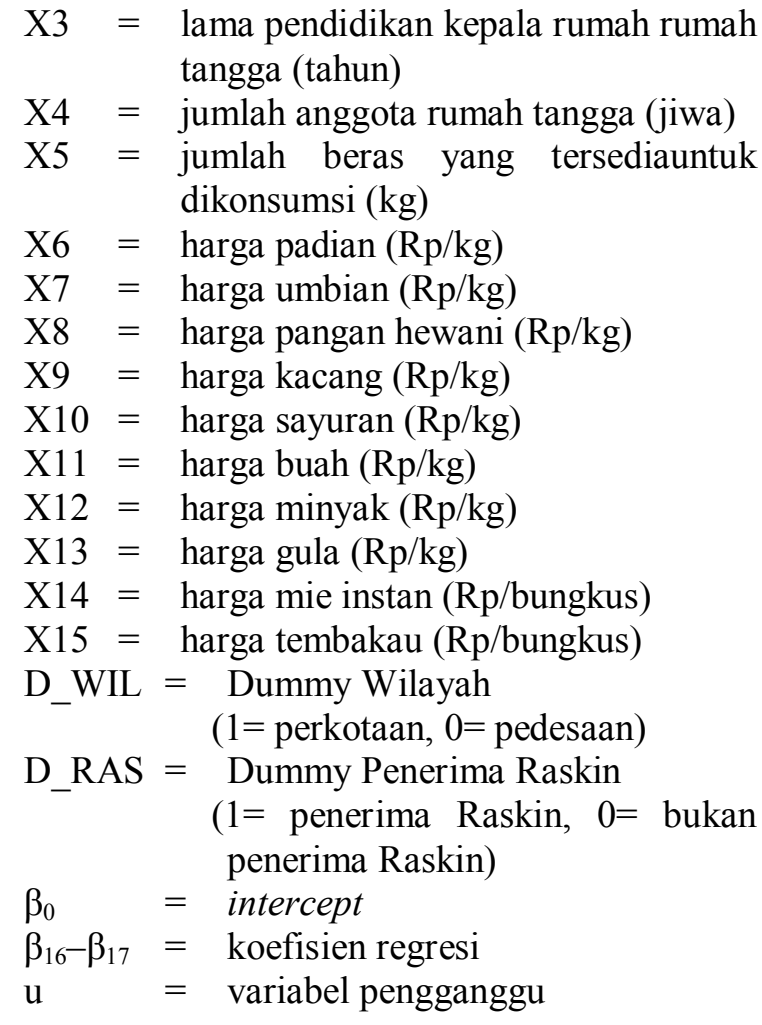

\section{HASIL DAN PEMBAHASAN}

Secara umum di Kabupaten Ciamis masih terdapat rumah tangga yang tidak tahan pangan.Distribusi rumah tangga menurut tingkat ketahanan pangan di Kabupaten Ciamis dapat dilihat pada Tabel 2.

Tabel 2 menunjukkan distribusi rumah tangga menurut tingkat ketahanan pangan. Berdasarkan metode Jonsson dan Toole terdapat rumah tangga rentan pangan sebanyak $530(54,08 \%)$, rumah tangga tahan pangan 264 $(26,94 \%)$, rumah tangga rawan pangan 124 $(12,65 \%)$ dan rumah tangga kurang pangan 62 $(6,33 \%)$.
Sedangkan berdasarkan metode modifikasi terdapat rumah tangga rentan pangan sebanyak 592 (60.41\%), tahan pangan 264 (26.94\%) dan rawan pangan 124 (12.65\%).

Rumah tangga rentan pangan merupakan rumah tangga dengan proporsi paling banyak, berdasarkan indikator yang digunakan, kelompok rumah tangga ini memiliki tingkat kecukupan energi yang cukup $(>80 \%)$, namun memiliki pangsa pengeluaran pangan yang tinggi $(>60 \%$ dari total pengeluaran rumah tangga.Kelompok rumah tangga ini secara ekonomi memiliki kemampuan ekonomi yang kurang, karena besarnyaproporsi pengeluaran rumah tangga yang dibelanjakan untuk pangan.

Intervensi yang dilakukan terhadap masing-masing kelompok rumah tangga berbeda. Pada rumah tangga rentan panganupaya penanganan kerawanan pangan diprioritaskan untuk meningkatkan pendapatan rumah tangga.Sedangkan untuk rumah tangga kurang pangan intervensi penanganan kerawanan pangan diprioritaskan pada upaya peningkatan pengetahuan pangan dan gizi.Intervensi untuk rumah tangga rawan pangan, dalam jangka pendek diperlukan bantuan pangan disertai bimbingan, peningkatan dan pemanfaatan sumberdaya keluarga untuk meningkatkan pendapatan, daya beli dan akses terhadap pangan (Rachman, 2005).

Identifikasi karakteristik rumah tangga dapat memperjelas kondisi ketahanan pangan rumah tangga yang meliputi: umur $\mathrm{KK}$, pendidikan KK, jumlah anggota rumah tangga, tingkat pendapatan dan tingkat kecukupan energi.Karakteristik rumah tangga dapat dilihat pada Tabel 3.

Tabel 2.Distribusi Rumah Tangga Menurut Tingkat Ketahanan Pangan Di Kabupaten Ciamis

\begin{tabular}{lccc}
\hline \multicolumn{2}{c}{ Metode } & \multicolumn{2}{c}{ Modifikasi Metode } \\
\hline $\begin{array}{c}\text { Tingkat } \\
\text { Ketahanan Pangan }\end{array}$ & Jumlah & $\begin{array}{c}\text { Tingkat } \\
\text { Ketahanan } \\
\text { Pangan }\end{array}$ & Jumlah \\
\hline Tahan Pangan & $264(26.94 \%)$ & Tahan Pangan & $264(26.94 \%)$ \\
Rentan Pangan & $530(54.08 \%)$ & Rentan Pangan & $592(60.41 \%)$ \\
Kurang Pangan & $62(6.33 \%)$ & Rawan Pangan & $124(12.65 \%)$ \\
Rawan Pangan & $124(12.65 \%)$ & Total & 980 \\
\hline Total & 980 & S &
\end{tabular}

Sumber: Analisis Data SUSENAS 2012. 
Tabel 3. Karakteristik Rumah Tangga Menurut Tingkat Ketahanan Pangan berdasarkan Metode Jonsson dan Toole di Kabupaten Ciamis

\begin{tabular}{|c|c|c|c|c|}
\hline \multirow{2}{*}{ Karakteristik } & \multicolumn{4}{|c|}{$\begin{array}{c}\text { Tingkat Ketahanan Pangan } \\
\text { Rumah Tangga }\end{array}$} \\
\hline & $\begin{array}{c}\text { Tahan } \\
\text { Pangan }\end{array}$ & $\begin{array}{l}\text { Rentan } \\
\text { Pangan }\end{array}$ & $\begin{array}{l}\text { Kurang } \\
\text { Pangan }\end{array}$ & $\begin{array}{l}\text { Rawan } \\
\text { Pangan }\end{array}$ \\
\hline$\overline{\text { Umur KK (tahun) }}$ & 51.51 & 52.10 & 47.82 & 53.81 \\
\hline Pendidikan KK (tahun) & 8.33 & 6.90 & 9.05 & 6.56 \\
\hline JART (jiwa) & 3.05 & 3.06 & 3.81 & 3.86 \\
\hline Pendapatan (000/bln) & 2.244 & 1.257 & 1.706 & 965 \\
\hline Pengeluaran Pangan (000/bln) & 1.004 & 866 & 762 & 662 \\
\hline & $44.74 \%$ & $68.89 \%$ & $44.67 \%$ & $68.60 \%$ \\
\hline Pengeluaran Non-Pangan (000/bln) & 1.240 & 391 & 944 & 303 \\
\hline & $55.26 \%$ & $31.11 \%$ & $55.33 \%$ & $31.40 \%$ \\
\hline Konsumsi Energi (kkal) & 2.232 & 2.234 & 1.415 & 1.406 \\
\hline$\% \mathrm{AKE}$ & $112 \%$ & $112 \%$ & $71 \%$ & $70 \%$ \\
\hline
\end{tabular}

Sumber: Analisis Data Susenas 2012

Tabel 3 menunjukan umur kepala rumah tangga tertinggi terdapat pada rumah tangga rawan pangan yaitu 53,81 tahun, selanjutnya rumah tangga rentan pangan 52,10 tahun, rumah tangga tahan pangan 51,51 dan rumah tangga kurang pangan 47,82 tahun. Umur kepala berhubungan dengan tingkat produktivitas, khususnya untuk pekerjaan yang memerlukan kekuatan fisik. Dengan bertambahnya umur, produktivitas akan berkurang, yang akan berdampak pada berkurangnya pendapatan rumah tangga.Pendidikan kepala rumah tangga yang paling lama terdapat pada rumah tangga kurangpangan 9,05 tahun, selanjutnya rumah tangga tahan pangan 8,33 tahun, rumah tangga rentan pangan 6,90 tahun dan rumah tangga rawan pangan 6,56 tahun. Pendidikan berhubungan dengan tingkat pengetahuan, yang akan mempengaruhi pola konsumsi pangan.

Jumlah anggota rumah tangga (JART) terbanyak terdapat pada rumah tangga rawan pangan sebanyak $3,86(\approx 4$ jiwa $)$, selanjutnya rumah tangga kurang pangan 3,81 jiwa $(\approx 4$ jiwa), rumah tangga rentan pangan 3,06 jiwa $(\approx$ 3 jiwa), dan rumah tangga tahan pangan 3,05 jiwa $(\approx 3$ jiwa). Apabila jumlah anggota rumah tangga meningkat, sedangkan pendapatan riil tetap akan menyebabkan penurunan daya beli rumah tangga. Hal ini akan menyebabkan konsumsi pangan rumah tangga akan menurun, selanjutnya akan berakibat pada turunnya tingkat ketahanan pangan rumah tangga.

Pendapatan didekati dari pengeluaran rumah tangga.Jumlah pendapatan terbanyak terdapat pada rumah tangga tahan pangan yaitu Rp 2.244.518/bulan. Pendapatan rumah tangga mempengaruhi aksesibilitas rumah tangga terhadap pangan akan semakin tinggi.

Persentase pengeluaran pangan terbesar terdapat pada rumah tangga rentan pangan $68,89 \%$. Proporsi pengeluaran pangan yang besar, menyebabkan kemungkinan rumah tangga menjadi tidak tahan pangan semakin besar.

Konsumsi energi terbanyak terdapat pada rumah tangga rentan pangan yaitu 2.234 kkal, selanjutnya rumah tangga tahan pangan 2.232 kkal, rumah tangga kurang pangan 1.415 kkal dan rumah tangga rawan pangan $1.406 \mathrm{kkal}$. Semakin besar konsumsi energi, tingkat ketahanan rumah tangga akan semakin tahan pangan.

Tabel 4 menunjukan umur kepala rumah tangga tertinggi terdapat pada rumah tangga rawan pangan yaitu 53.81 tahun, selanjutnya rumah tangga rentan pangan 52.10 tahun dan rumah tangga tahan pangan 51.51 tahun.Umur kepala berhubungan dengan tingkat produktivitas, khususnya untuk pekerjaan yang memerlukan kekuatan fisik. Dengan bertambahnya umur, produktivitas akan berkurang, yang akan berdampak pada berkurangnya pendapatan rumah tangga.

Pendidikan kepala rumah tangga yang paling lama terdapat pada rumah tangga tahan pangan 8,33 tahun, selanjutnya rumah tangga rentan pangan 7,13 tahun dan rawan pangan 6,56 tahun.Pendidikan berhubungan dengan 
Asep H., Dwidjono H. D., Jangkung H. M. : Ketahanan pangan rumah tangga...

Tabel 4. Karakteristik Rumah Tangga Menurut Tingkat Ketahanan Pangan Berdasarkan Modifikasi Metode Jonsson dan Toole di Kabupaten Ciamis

\begin{tabular}{lrrr}
\hline \multirow{2}{*}{ Karakteristik } & \multicolumn{2}{c}{ Tingkat Ketahanan Pangan } \\
\cline { 2 - 4 } \multicolumn{1}{c}{ Tahan Pangan } & Rentan Pangan & Rawan Pangan \\
\hline Umur KK (tahun) & 51,51 & 52,10 & 53,81 \\
Pendidikan KK (tahun) & 8,33 & 7,13 & 6,56 \\
JART (jiwa) & 3,05 & 3,14 & 3,86 \\
Pendapatan (Rp/bln) & 2.244 .518 & 1.304 .472 & 965.577 \\
Pengeluaran Pangan (Rp/bln) & 1.004 .349 & 855.337 & 662.453 \\
& $(44,75 \%)$ & $(65,57 \%)$ & $(68.60 \%)$ \\
Pengeluaran Non-Pangan & 1.240 .169 & 449.135 & 303.124 \\
(Rp/bln) & $(55,25 \%)$ & $(34,34 \%)$ & $(31.40 \%)$ \\
Konsumsi Energi (kkal) & 2.232 & 2.148 & 1.406 \\
\% AKE & $111,59 \%$ & $107,40 \%$ & $70 \%$ \\
\hline
\end{tabular}

Sumber: Analisis Data Susenas 2012

Tabel 5. Hasil Analisis Regresi Faktor-Faktor yang Mempengaruhi Ketahanan Pangan Rumah Tangga di Kabupaten Ciamis Menggunakan Metode Jonsson dan Toole.

\begin{tabular}{|c|c|c|c|}
\hline variabel & $\begin{array}{l}\text { expected } \\
\text { sign }\end{array}$ & coefficient & prob \\
\hline Pendapatan & + & $2.115086^{* * *}$ & 0.0000 \\
\hline Umur & + & 0.201060 & 0.2153 \\
\hline Pendidikan & + & 0.152922 & 0.2794 \\
\hline JART & - & $-3.314193 * * *$ & 0.0000 \\
\hline Jmlh_beras & + & $1.251839 * * *$ & 0.0000 \\
\hline H_padian & - & -0.044813 & 0.8504 \\
\hline H_umbian & - & 0.027474 & 0.6960 \\
\hline H_phewani & - & $-0.336803 * * *$ & 0.0050 \\
\hline H_kacang & - & -0.145538 & 0.3973 \\
\hline H_sayur & - & -0.043827 & 0.6213 \\
\hline $\mathrm{H}^{-}$buah & - & -0.077699 & 0.2499 \\
\hline H_minyak & - & $-1.079488 * * *$ & 0.0000 \\
\hline H_gula & - & 0.015932 & 0.9266 \\
\hline H_mie & - & -0.585478 & 0.1076 \\
\hline H_tembakau & - & -0.131571 & 0.3741 \\
\hline D_WIL & & $-0.203484 * *$ & 0.0298 \\
\hline D_RAS & & 0.042738 & 0.6274 \\
\hline \multicolumn{4}{|c|}{ Limit Points } \\
\hline LIMIT_2:C(18) & 6.469544 & & \\
\hline LIMIT_3:C(19) & 6.889343 & & \\
\hline LIMIT_4:C(20) & 9.024157 & & \\
\hline Log likēlihood & -822.1947 & & \\
\hline Restr. log likelihood & -1099.529 & & \\
\hline LR statistic (17 df) & 554.6683 & & \\
\hline Probability(LR stat) & 0.000000 & & \\
\hline LR index (Pseudo-R ${ }^{2}$ ) & 0.252230 & & \\
\hline
\end{tabular}

Sumber: Analisis Data Susenas 2012

Keterangan:

*** : berpengaruh nyata pada $\alpha 1 \%$

** : berpengaruh nyata pada $\alpha 5 \%$

* $\quad$ : berpengaruh nyata pada $\alpha 10 \%$ 
tingkat pengetahuan, yang akan mempengaruhi pola konsumsi pangan.

Jumlah anggota rumah tangga (JART) terbanyak terdapat pada rumah tangga rawan pangan sebanyak $3,86(\approx 4$ jiwa $)$, selanjutnya rumah tangga rentan pangan 3,14 jiwa $(\approx 3$ jiwa), dan rumah tangga tahan pangan 3,05 jiwa $(\approx 4$ jiwa). Apabila jumlah anggota rumah tangga meningkat, sedangkan pendapatan riil tetap akan menyebabkan penurunan daya beli rumah tangga.Hal ini akan menyebabkan konsumsi pangan rumah tangga akan menurun, selanjutnya akan berakibat pada turunnya tingkat ketahanan pangan rumah tangga.

Pendapatan didekati dari pengeluaran rumah tangga.Jumlah pendapatan terbanyak terdapat pada rumah tangga tahan pangan yaitu Rp 2.244.518/bulan.Pendapatan rumah tangga mempengaruhi aksesibilitas rumah tangga terhadap pangan akan semakin tinggi.

Persentase pengeluaran pangan terbesar terdapat pada rumah tangga rentan pangan $65,57 \%$.Proporsi pengeluaran pangan yang besar, menyebabkan kemungkinan rumah tangga menjadi tidak tahan pangan semakin besar.

Konsumsi energi terbanyak terdapat pada rumah tangga tahan pangan yaitu $2.234 \mathrm{kkal}$, selanjutnya rumah tangga rentan pangan 2.148 kkal dan rawan pangan 1.406 kkal.Semakin besar konsumsi energi, tingkat ketahanan rumah tangga akan semakin tahan pangan. Angka konsumsi energi pada rumah tangga tahan pangan dan rentan pangan telah melebihi tingkat kecukupan yang dianjurkan sebesar $2.000 \mathrm{kkal}$.

Tabel 6. Hasil Analisis Regresi Faktor-Faktor yang Mempengaruhi Ketahanan Pangan Rumah Tangga Di Kabupaten Ciamis Menggunakan Modifikasi Metode Jonsson dan Toole.

\begin{tabular}{lcll}
\hline \multicolumn{1}{c}{ Variabel } & $\begin{array}{c}\text { expected } \\
\text { sign }\end{array}$ & coefficient & Prob. \\
\hline Pendapatan & + & $2.340964^{* * * *}$ & 0.0000 \\
Umur & + & 0.284305 & 0.1006 \\
Pendidikan & + & $0.321664^{* *}$ & 0.0345 \\
JART & - & $-3.155986^{* * *}$ & 0.0000 \\
Jmlh_beras & + & $0.930698^{* * *}$ & 0.0000 \\
H_padian & - & 0.020021 & 0.9377 \\
H_umbian & - & 0.053602 & 0.4736 \\
H_phewani & - & $-0.509221^{* * *}$ & 0.0001 \\
H_kacang & - & -0.020089 & 0.9159 \\
H_sayur & - & -0.051959 & 0.5873 \\
H_buah & - & -0.061092 & 0.3973 \\
H_minyak & - & $-1.161957^{* * *}$ & 0.0000 \\
H_gula & - & 0.044110 & 0.8115 \\
H_mie & - & -0.630557 & 0.1089 \\
H_tembakau & - & -0.171687 & 0.2773 \\
D_WIL & & $-0.183827^{*}$ & 0.0671 \\
D_RAS & & -0.019122 & 0.8390 \\
LIMIT_2:C(18) & 8.836303 & Limit Points & \\
LIMIT_3:C(19) & 11.50844 & & \\
Log likelihood & -623.3815 & & \\
Restr. log likelihood & -901.0001 & & \\
LR statistic (17 df) & 555.2372 & & \\
Probability(LR stat) & 0.000000 & & \\
LR index (Pseudo-R $\left.{ }^{2}\right)$ & 0.308123 & & \\
\hline Sumber: Analisis Data & - & &
\end{tabular}

Sumber: Analisis Data Susenas 2012

Keterangan:

*** : berpengaruh nyata pada $\alpha 1 \%$

** : berpengaruh nyata pada $\alpha 5 \%$

* $\quad$ : berpengaruh nyata pada $\alpha 10 \%$ 
Untuk mengetahui faktor-faktor yang berpengaruh terhadap ketahanan pangan rumah tangga di Kabupaten Ciamis, dilakukan analisis regresi model ordinal probit.Hasil analisis regresi dapat dilihat pada tabel 5 .

Tabel 5 menunjukan nilai $L R$ index (Pseudo-R2) sebesar 0.252230. Hal ini menunjukan bahwa $25,22 \%$ variasi ketahanan pangan rumah tangga (variabel dependen) dapat dijelaskan oleh faktor-faktor yang ada dalam model (variabel independen), sedangkan sisanya sebesar $74,78 \%$ dijelaskan oleh faktor yang ada diluar model.

Selanjutnya berdasarkan hasil perhitungan, dapat dinyatakan bahwa probabilitas rumah tangga di Kabupaten Ciamis untuk menjadi rawan pangan sebesar 23,27\%, kurang pangan sebesar $43,01 \%$, rentan pangan $20,80 \%$, dan tahan pangan sebesar $12,92 \%$.

Variabel independen yang berpengaruh signifikan terhadap model ketahanan pangan rumah tangga adalah: pendapatan rumah tangga, jumlah anggota rumah tangga, jumlah beras yang tersedia untuk dikonsumsi, harga kelompok pangan hewani dan harga minyak dengan tingkat signifikansi $\alpha 1 \%$ kecuali untuk variabel wilayah tempat tinggal tingkat signifikansi pada $\alpha 5 \%$.

Sedangkan hasil analisis regresi faktorfaktor yang mempengaruhi ketahanan pangan rumah tangga di Kabupaten Ciamis menggunakan modifikasi metode Jonsson dan Toole disajikan pada Tabel 6 .

Tabel 6 menunjukan nilai $L R$ index (Pseudo-R2) sebesar 0.308123. Hal ini menunjukan bahwa $30,81 \%$ variasi ketahanan pangan rumah tangga (variabel dependen) dapat dijelaskan oleh faktor-faktor yang ada dalam model (variabel independen), sedangkan sisanya sebesar $69,19 \%$ dijelaskan oleh faktorfaktor yang ada diluar model.

Selanjutnya hasil analisis dengan metode modifikasi klasifikasi silang menghasilkan probabilitas rumah tangga di Kabupaten Ciamis menjadi rawan pangan sebesar $23,89 \%$, rentan pangan $52,22 \%$, dan tahan pangan $23,89 \%$.

Variabel independen yang berpengaruh signifikan terhadap model ketahanan pangan rumah tangga adalah: pendapatan rumah tangga, jumlah anggota rumah tangga, jumlah beras yang tersedia untuk dikonsumsi, harga kelompok pangan hewani dan harga kelompok pangan minyak dengan tingkat signifikansi $\alpha$
$1 \%$, pendidikan kepala keluarga pada $\alpha 5 \%$ dan dummy wilayah pada $\alpha 10 \%$.

Pendapatan rumah tangga. Hasil analisis regresi menunjukan tanda koefisien sesuai dengan expected sign, yaitu positif. Semakin tinggi pendapatan rumah tangga, akan semakin tinggi tingkat ketahanan pangan rumah tangga. Tingkat pendapatan yang semakin tinggi secara ekonomi akan meningkatkan tingkat kesejahteraan rumah tangga. Pendapatan rumah tangga akan mempengaruhi pengeluaran rumah tangga, yang pada akhirnya akan mempengaruhi tingkat konsumsi pangan. Peningkatan pendapatan ini akan meningkatkan daya beli rumah tangga, sehingga akses ekonomi terhadap pemenuhan pangan akan lebih mudah (Omotesho, 2007). Menurut Purwaningsih (2010) pendapatan rumah tangga yang dimiliki akan memberikan kemampuan daya beli untuk membeli sesuatu yang lebih baik termasuk untuk memperoleh pangan yang lebih baik.

Jumlah anggota rumah tangga (JART) memiliki tanda koefisien sesuai dengan expected sign, yaitu negatif. Hal ini menggambarkan semakin banyak jumlah anggota rumah tangga akan menurunkan tingkat ketahanan pangan rumah tangga. Apabila jumlah anggota rumah tangga meningkat, sedangkan pendapatan riil tetap akan menyebabkan penurunan daya beli rumah tangga. Hal ini akan menyebabkan konsumsi pangan rumah tangga akan menurun, selanjutnya akan berakibat pada turunnya tingkat ketahanan pangan rumah tangga. Semakin banyak jumlah anggota rumah tangga akan mengakibatkan jumlah pangan yang harus disediakan untuk dikonsumsi dalam rumah tangga tersebut semakin banyak, sehingga proporsi pengeluaran rumah tangga untuk pangan akan semakin besar. Pendapatan yang dimiliki oleh rumah tangga akan dialokasikan lebih banyak untuk pengeluaran pangan (Omotheso, 2007). Sedangkan rumah tangga dengan jumlah anggota rumah tangga yang sedikit, proporsi pengeluaran rumah tangga akan semakin berkurang. Hal tersebut akan menyebabkan kondisi ketahanan pangan rumah tangga semakin baik.

Jumlah beras yangtersedia untuk dikonsumsi.Beras merupakan makan pokok penduduk di Kabupaten Ciamis. Jumlah beras yang tersedia untuk dikonsumsi, akan 
mempengaruhi tingkat ketahanan pangan rumah tangga. Semakin banyak jumlah beras yang tersedia, konsumsi beras rumah tangga akan semakin besar. Dengan banyaknya konsumsi beras, maka asupan energi akan semakin banyak. Jumlah kalori yang terdapat pada beras sebasar $1.290 \mathrm{kkl} / \mathrm{kg}(65 \%$ dari AKG). Jumlah asupan energi ini akan menentukan tingkat kecukupan energi. Sebaliknya jika jumlah ketersediaan beras untuk dikonsumi sedikit, maka konsumsi beras akan kurang, yang berakibat pada asupan energi yang berkurang, yang pada akhirnya akan menyebabkan tingkat kecukupan energi juga akan berkurang. Tingkat kecukupan energi yang sedikit, akan mengakibatkan tingkat ketahanan pangan rumah tangga semakin rawan pangan.

Harga pangan.Secara umum harga pangan berpengaruh negatif terhadap tingkat ketahanan pangan rumah tangga, semakin tinggi harga pangan maka rumah tangga akan semakin tidak tahan pangan. Harga pangan yang meningkat akan berpengaruh terhadap rumah tangga yang memiliki pendapatan tetap, karena akan menurunkan pendapatan riil rumah tangga. Dengan pendapatan riil yang menurun, rumah tangga akan menghadapi penurunan daya beli yang berakibat pada keterbatasan dalam memenuhi konsumsi pangan. Rumah tangga akan mengurangi jumlah pangan untuk dikonsumsi, yang berakibat pada menurunnya tingkat kecukupan energi dan pada akhirnya akan menyebabkan tingkat ketahanan pangan tangga menjadi menurun.

Harga kelompok bahan pangan yang berpengaruh pada tingkat ketahanan pangan rumah tangga di Kabupaten Ciamis adalah harga kelompok pangan hewani dan harga kelompok pangan minyak. Kelompok pangan hewani dikonsumsi oleh 98\% rumah tangga, dengan harga rata-rata sebesar Rp 24,463/kg, merupakan kelompok bahan pangan yang memiliki harga rata-rata paling tinggi. Kelompok pangan minyak (dan lemak) dikonsumsi oleh 99\% rumah tangga, dengan harga rata-rata sebesar $\mathrm{Rp} 10,873 / \mathrm{kg}$. Pemenuhan kebutuhan konsumsi kedua kelompok bahan pangan ini diperoleh dengan carapembelian, sehingga apabila harga mengalami kenaikan akan menurunkan jumlah konsumsi pangan tersebut.
Pendidikan kepala rumah tangga berpengaruh positif terhadap tingkat ketahanan pangan rumah tangga. Semakin lama pendidikan kepala rumah tangga akan meningkatkan tingkat ketahanan pangan rumah tangga. Pendidikan kepala rumah tangga berhubungan dengan pekerjaan. Umumnya tingkat pendidikan yang lebih tinggi akan memperoleh pekerjaan yang lebih baik. Dengan demikian maka kepala rumah tangga akan mendapatkan pendapatan yang relatif lebih tinggi, sehingga dapat mengalokasikan pendapatannya untuk memenuhi kebutuhan pangan yang lebih baik, jumlah maupun kualitasnya.

Terdapat perbedaan tingkat ketahanan pangan rumah tangga antara wilayah perkotaan dan pedesaan.Rumah tangga yang bertempat tinggal di pedesaan lebih tahan pangan dibandingkan dengan rumah tangga yang berada di wilayah perkotaan.Hal ini dapat dijelaskan pada Tabel7.

Tabel 7. Perbedaan Keadaan Wilayah Kota dan Desa.

\begin{tabular}{lrr}
\hline & Kota & \multicolumn{1}{l}{ Desa } \\
\hline Jumlah rumah tangga & $28.06 \%$ & $71.94 \%$ \\
$\begin{array}{l}\text { Rata-rata jumlah } \\
\text { anggota rumah tangga }\end{array}$ & 3,48 & 3,10 \\
$\begin{array}{l}\text { (jiwa) } \\
\text { Rumah tangga dengan } \\
\text { mata pencaharian di } \\
\text { bidang pertanian }\end{array}$ & $5.71 \%$ & $30.20 \%$ \\
$\begin{array}{l}\text { Jumlah beras yang } \\
\text { tersedia untuk } \\
\text { dikonsumsi (kg/orang) }\end{array}$ & $1.90 \mathrm{~kg}$ & $2.03 \mathrm{~kg}$ \\
\hline
\end{tabular}

Sumber: Analisis Data Susenas 2012.

Berdasarkan Tabel 7 sebesar $\quad 71,94 \%$ rumah tangga tinggal di pedesaan, 30,20\% diantaranya memiliki mata pencaharian di sektor pertanian. Dengan rata-rata jumlah kepemilikan beras untuk di konsumsi sebesar $6,31 \mathrm{~kg} /$ rumah tangga dan jumlah anggota rumah tangga sebanyak 3.10 jiwa maka jumlah beras yang tersedia untuk dikonsumsi di pedesaan sebesar 2,03 kg/jiwa lebih besar dari rumah tangga perkotaan sebanyak $1,09 \mathrm{~kg} /$ jiwa.

Penelitian ini juga memberikan informasi bahwa tidak ada perbedaan tingkat ketahanan pangan antara rumah tangga penerima bantuan Raskin dan non Raskin.Program bantuan Raskin bertujuan untuk meningkatkan 
pemenuhan kebutuhan pangan bagi masyarakat miskin berpenghasilan rendah, agar dapat memperkuat ketahanan pangan di tingkat rumah tangga.Namun dalam penyalurannya masih terdapat salah sasaran.Hal ini dapat dilihat dari distribusi rumah tangga penerima bantuan Raskin di Kabupaten Ciamis pada tahun 2012, seperti terlihat pada Tabel8.

Tabel 8. Distribusi Rumah Tangga Penerima Bantuan RASKIN menurut Tingkat Ketahanan Pangan di Kabupaten Ciamis

\begin{tabular}{|c|c|c|c|}
\hline \multicolumn{2}{|c|}{$\begin{array}{c}\text { Metode } \\
\text { Jonsson dan Toole }\end{array}$} & \multicolumn{2}{|c|}{$\begin{array}{c}\text { Metode } \\
\text { Modifikasi }\end{array}$} \\
\hline Tingkat & Jumlah & Tingkat & Jumlah \\
\hline Ketahanan & Rumah & Ketahanan & Rumah \\
\hline Pangan & Tangga & Pangan & Tangga \\
\hline Tahan & 130 & Tahan & 130 \\
\hline Pangan & $(21,17 \%)$ & Pangan & $(21,17 \%)$ \\
\hline Rentan & 365 & & \\
\hline Pangan & $(59,45 \%)$ & Rentan & 392 \\
\hline Kurang & 27 & Pangan & $(63,84 \%)$ \\
\hline Pangan & $(4,40 \%)$ & & \\
\hline Rawan & 92 & Rawan & 92 \\
\hline Pangan & $(14,98 \%)$ & Pangan & $(14,98 \%)$ \\
\hline Total & 614 & Total & 614 \\
\hline
\end{tabular}

Sumber: Analisis Data SUSENAS 2012.

Tabel 8 menunjukan bahwa jumlah rumah tangga penerima bantuan Raskin sebanyak 614 rumah tangga.Berdasarkan metode Jonsson dan Toole, rumah tangga yang paling banyak menerima bantuan RASKIN adalah kelompok rumah tangga rentan pangan sebanyak $365(59,45 \%)$, selanjutnya rumah tangga tahan pangan $130(21,17 \%)$, rumah tangga rawan pangan $92(14,98 \%)$ dan rumah tangga kurang pangan 27 (4,40\%).

Sedangkan distribusi rumah tangga penerima bantuan Raskin berdasarkan modifikasi metode sebanyak $392(63,84 \%)$, selanjutnya rumah tangga tahanpangan sebanyak $130(21,17 \%)$ dan rumah tangga rawan pangan 92 (14,98\%).Distribusi rumah tangga tersebut menunjukan bahwa rumah tangga tahan pangan lebih banyak menerima bantuan RASKIN dibandingkan dengan rumah tangga yang tidak tahan pangan. Hal ini tidak sesuai dengan prinsip 6 TEPAT dalam penyaluran bantuan RASKIN, yaitu diantaranya TEPAT SASARAN, dimana bantuan RASKIN ditujukan untuk rumah tangga miskin agar dapat meningktkan ketahanan pangan keluarga/rumah tangga.

Hasil analisis regresi menunjukan perbedaan antara metode awal klasifikasi silang dan metode hasil modifikasi.Perbedaan tersebut dapat dilihat pada Tabel 9.

Tabel 9. Perbedaan Hasil Analisis Regresi Antara Modifikasi Jonsson dan Toole dan Modifikasi Metode

\begin{tabular}{|c|c|c|}
\hline Perbedaan & $\begin{array}{c}\text { Metode } \\
\text { Jonsson } \\
\text { dan Toole }\end{array}$ & $\begin{array}{l}\text { Metode } \\
\text { Modifikasi }\end{array}$ \\
\hline$L R$ index (Pseudo-R2) & $\begin{array}{l}0.252230 \\
(25.22 \%)\end{array}$ & $\begin{array}{l}0.308123 \\
(30.81 \%)\end{array}$ \\
\hline Faktor berpengaruh & 6 variabel & 7 variabel \\
\hline \multicolumn{3}{|c|}{ Probabilitas rumah tangga: } \\
\hline Tahan pangan & Tahan pangan & $23,89 \%$ \\
\hline $\begin{array}{ll}\text { Rentan pangan } & 20.80 \% \\
\text { Kurang pangan } & 43.01 \%\end{array}$ & Rentan pangan & $52,22 \%$ \\
\hline Rawan panan $23.27 \%$ & Rawan pangan & $23,89 \%$ \\
\hline
\end{tabular}

Tabel 9 menunjukan nilai $L R$ index (Pseudo-R2) yang menggambarkan kebaikan model pada hasil regresi pada metode modifikasi klasifikasi silang sebesar 0.308123 $(30,81)$ lebih besar dibandingkan Nilai $L R$ index (Pseudo-R2) pada metode awal klasifikasi silang sebesar 0.252230 (25,22\%). Hal ini mengindikasikan bahwa kebaikan model untuk menganalisis faktor yang berpengaruh terhadap ketahanan pangan rumah tangga di Kabupaten Ciamis lebih baik menggunakan metode modifikasi klasifikasi silang dengan 3 tingkat ketahanan pangan, dari pada metode awal klasifikasi silang yang menggunakan 4 tingkat ketahanan pangan.

Pengukuran tingkat ketahanan pangan rumah tangga di Kabupaten Ciamis, lebih baik menggunakan 3 tingkat ketahanan pangan berdasarkan modifikasi metode klasifikasi silang, dengan urutan tingkatan: tahan pangan, rentan pangan dan rawan pangan.

\section{KESIMPULAN DAN SARAN}

Distribusi rumah tangga di Kabupaten Ciamis menurut tingkat ketahanan pangan pada tahun 2012 berdasarkan metode Jonsson dan Toole adalah: 54,08\%rumah tangga rentan pangan, $26,94 \%$ rumah tangga tahan pangan, $12,65 \%$ rumah tangga rawan pangan dan $6,33 \%$ rumah 
tangga kurang pangan.Sedangkan berdasar modifikasi metode Jonsson dan Toole: $60,41 \%$ rumah tangga rentan pangan, 26,94\% rumah tangga tahan pangan dan $12,65 \%$ rumah tangga rawan pangan.

Rumah tangga di wilayah pedesaan lebih tahan pangan dibandingkan dengan rumah tangga di wilayah perkotaan.Faktor-faktor yang berpengaruh terhadap ketahanan pangan rumah tangga adalah pendapatan rumah tangga, jumlah beras yang dimiliki untuk dikonsumsi, umur kepala rumah tangga, lama pendidikan kepala keluarga, jumlah anggota keluarga, harga pangan hewani dan harga minyak.

Pemberian bantuan RASKIN di Kabupaten Ciamis, tidak memberikan perbedaan tingkat ketahanan pangan rumah tangga, hal ini dimungkinkan oleh tidak tepatnya sasaran penerima bantuan RASKIN.Untuk itu disarankan adanya evaluasi terhadap distribusi/ penyaluran bantuan RASKIN.

Pengukuran tingkat ketahanan pangan rumah tangga di Kabupaten Ciamis, disarankan lebih baik menggunakan 3 (tiga) tingkat ketahanan pangan berdasarkan modifikasi metode Jonsson dan Toole, yang menghasilkan tingkatan ketahanan pangan: tahan pangan, rentan pangan dan rawan pangan.

\section{DAFTAR PUSTAKA}

Anonim, 2005.Peta Kerawanan Pangan/Food Insecurity Atlas-FIA.Dewan Ketahanan Pangan. Jakarta.

, 2006. Kebijakan Umum Ketahanan Pangan Nasional 2006-2009. Dewan Ketahanan Pangan. Jakarta.

2009. Peta Ketahanan dan Kerentanan Pangan/Food Security and Vulnerability Atlas-FSVA.Dewan Ketahanan Pangan. Jakarta.

, 2010. Rencana Strategis Badan Ketahanan Pangan 2010-2014. Badan Ketahanan Pangan. Departemen Pertanian. Jakarta.

2012. Undang-Undang Nomor18 tahun 2012 Tentang Pangan, Dewan Ketahanan Pangan. Jakarta.
Darwanto, Dwidjono Hadi. 2005. Ketahanan Pangan Berbasis Produksi dan Kesejahteraan Petani. Jurnal Ilmu Pertanian 12 (2): 152-164.

Hanani, Nuhfil. 2012. Strategi Pencapaian Ketahanan Pangan Keluarga. E-Jurnal Ekonomi Pertanian. 1 (1): 1 10. PERHEPI. Bogor.

Maxwell, Daniel. Levin, Carol. Klemesu, Margaret Armar. Ruel, Marie. Morris, Saul. Ahiadeke, Clement. 2000. Urban Livelihood and Food an Nutrien Security in Greater Accra, Ghana. IFRI. Washington DC.

Omotheso, O.A., Adewumi, M.O., Lawal Muhammad A. and Ayinde, O.E. 2007.Food Security and Poverty of the Rural Household in Kwara State, Nigeria A.A.A.E Conference Proceeding.Departement of Agriculture Economic and Fram Management, Faculty Of Agriculture. University of Ilorin. Nigeria

Purwantini, Bastuti, T., Rachman H.P.S., dan Marisa Y. 2007.Analisis Ketahanan Pangan Regional dan Tingkat Rumah Tangga: Studi Kasus di Propinsi Sulawesi Utara.Pusat Analisis Sosial Ekonomi dan Kebijakan Pertanian.Badan Penelitian dan Pengembangan Pertanian. Departemen Pertanian. Bogor

Rachman, Handewi P.S., M. Aryani dan T.B. Purwantini, 2005. Distribusi Provinsi di Indonesia menurut Derajat Ketahanan Pangan Rumah Tangga.Pusat Analisis Sosial Ekonomi dan Kebijakan Pertanian.Badan Penelitian dan Pengembangan Pertanian. Departemen pertanian. Bogor.

Suharyanto, 2014. Dampak Penerapan Pengelolaan Tanaman Terpadu (PTT) Padi Sawah Terhadap Produksi, Efisiensi, Pendapatan Dan Ketahanan Pangan Rumahtangga Petani Di Provinsi Bali.Disertasi. Universitas Gadjah Mada. Tidak Dipublikasikan. 
Asep H., Dwidjono H. D., Jangkung H. M. : Ketahanan pangan rumah tangga...

Suryana, Achmad, 2003. Kapita Selekta Evolusi Pemikiran Kebijakan Ketahanan Pangan. BPFE.Yogyakarta.
Suryana, Achmad, 2007. Menelisik Upaya Menggapai Ketahanan Pangan Nasional. Badan Penelitian dan Pengembangan Pertanian. Departemen Pertanian. Jakarta. 